\title{
Grouper and snapper movements and habitat use in Dry Tortugas, Florida
}

\author{
Nicholas A. Farmer ${ }^{1,2, *}$, Jerald S. Ault ${ }^{1}$ \\ ${ }^{1}$ Rosenstiel School of Marine and Atmospheric Science, Division of Marine Biology and Fisheries, University of Miami, \\ 4600 Rickenbacker Causeway, Miami, Florida 33149, USA \\ ${ }^{2}$ NOAA National Marine Fisheries Service, Southeast Regional Office, 263 13th Avenue South, St. Petersburg, Florida 33701, USA
}

\begin{abstract}
Home ranges, activity patterns, and habitat preferences in and around no-take marine reserves (NTMRs) were evaluated for 5 exploited snapper-grouper species in diverse coral reef habitats in the Dry Tortugas, Florida. Movements of ultrasonic tagged reef fish were determined using a calibrated array of omnidirectional hydroacoustic receivers. Average home range sizes were $2.09 \pm$ $0.39 \mathrm{~km}^{2}$ ( $\mathrm{n}=28$; total length, $\mathrm{TL}=45$ to $66 \mathrm{~cm}$ ) for red grouper Epinephelus morio, $4.17 \pm 1.75 \mathrm{~km}^{2}$ ( $\mathrm{n}=5, \mathrm{TL}=48$ to $55 \mathrm{~cm}$ ) for yellowtail snapper Ocyurus chrysurus, $1.44 \pm 1.04 \mathrm{~km}^{2}(\mathrm{n}=2, \mathrm{TL}=57$ to $75 \mathrm{~cm}$ ) for black grouper Mycteroperca bonaci, and $7.64 \mathrm{~km}^{2}(\mathrm{n}=1, \mathrm{TL}=70 \mathrm{~cm}$ ) for mutton snapper Lutjanus analis. Red grouper and yellowtail snapper moved moderate distances (from 700 to $900 \mathrm{~m}$ ) with moderate frequency. Observed movements for black groupers were relatively small and infrequent. Mutton snappers appeared to make short, frequent movements. A tracked gray snapper L. griseus made long-distance nocturnal migrations. Several exploited-phase groupers and snappers crossed into and out of reserve boundaries. They were most likely to do so in locations where boundaries were positioned over contiguous coral reef and close to home-range centers. We found that home ranges for red grouper, black grouper, and yellowtail snapper were relatively small in comparison to NTMR area. Our observations suggest that the Dry Tortugas NTMRs may reduce exposure to exploitation for these and other species with limited home ranges, especially where NTMR boundaries do not overlie contiguous reef.
\end{abstract}

KEY WORDS: Acoustic tracking $\cdot$ Snapper-grouper complex $\cdot$ Movement patterns $\cdot$ Home range Marine reserves $\cdot$ Coral reef fishes

Resale or republication not permitted without written consent of the publisher

\section{INTRODUCTION}

The Florida coral reef ecosystem, stretching $220 \mathrm{~km}$ southwest from Miami to the Dry Tortugas, supports multibillion dollar tourism and fishing industries (Ault et al. 2005a). However, the region's lucrative multispecies snapper-grouper complex has been serially overfished since at least the late 1970s (Ault et al. 1998, 2005b, 2009).

The Dry Tortugas region, because of its relative isolation and upstream location where the Florida Current merges into the Gulf Stream, has long supported the Florida Keys reef fishery with recruits from regional spawning, and density-dependent emigration of adult biomass (Schmidt et al. 1999, Ault et al. 2006b). Because of growing stress on regional fisheries and coral reefs, in January 2007, the National Park Service established a no-take marine reserve (NTMR), or Research Natural Area (RNA), covering $158 \mathrm{~km}^{2}$ of prime shallow-water reef habitat in the western half of Dry Tortugas National Park (DTNP). The eastern half of DTNP (101 km²) has been closed to commercial fishing, recreational spearfishing, and lobstering since the 1960s. It is, however, open to recreational hook-andline fishing. The RNA was designed as a shallow-water complement to 2 relatively large NTMRs (Tortugas North and South Ecological Reserves), established in 2001 by the National Oceanic and Atmospheric Administration (NOAA) in the Florida Keys National Marine Sanctuary (FKNMS). At the time of their implementation this was the largest regional network of NTMRs in the US, protecting unique and fragile coral 
reef habitats and helping to sustain the region's worldclass fisheries resources. Evidence has already emerged that they are reaching their intended goals (Ault et al. 2006b).

Many marine fishes repeatedly use and move throughout particular areas, or home ranges (Burt 1943), for certain periods of the year or for particular life stages (Goeden 1978, Shapiro et al. 1994, Rooij et al. 1996, Zeller 1997, Kramer \& Chapman 1999, Bell \& Kramer 2000, Bolden 2001, Eristhee \& Oxenford 2001, Baras et al. 2002, Lembo et al. 2002, Parsons et al. 2003). Occupation by marine fishes of a particular home range within a spatially heterogeneous landscape - given increased familiarity with key habitat features - may facilitate evasion of predators and increase foraging efficiency (review in Harris et al. 1990).

Quantifying short- and longer-term fish movement patterns, home ranges, and habitat use is critical for advancing understanding of the dynamics of reef-fish community ecology and for informing intelligent NTMR design (Russ \& Alcala 1996, Palumbi 2001, Meester et al. 2004, O'Dor et al. 2004). Unfortunately, data of this type are extremely limited (Kramer \& Chapman 1999, Meyer et al. 2007). As a result, most reserves have been implemented with little quantitative design analysis, and this 'faith-based' approach has generated over-confidence about resource productivity and protection (Eristhee \& Oxenford 2001, Meester et al. 2001, 2004, Hilborn 2006).

There is a broad scientific and management interest in improving our understanding of how the Tortugas NTMRs may facilitate the rebuilding of regional reef fisheries and help to conserve and sustain marine biodiversity in the Florida coral reef ecosystem. However, improperly configured NTMRs that underestimate the magnitude of animal movements and resultant vulnerability to exploitation may deleteriously affect NTMR capacity to buffer against exploitation pressure and sustain regional productivity (Eklund et al. 2000, Eristhee \& Oxenford 2001). Anti-reserve lobby groups, on the other hand - due to a misinterpretation of a tagging study by Tremain et al. (2004) - have claimed that NTMR implementation was management 'double-dipping'. In their proposed scenario, not only would the NTMR function as a sink for fisheries resources, but it would also attract animals from fished areas, who themselves would never again be vulnerable to the fisheries.

In this paper, we principally focus on describing movements of red grouper determined from novel application of acoustic telemetry in the rugose and complex coral reef habitats of the Dry Tortugas, Florida. To broaden the interpretation, auxiliary data for 4 other key exploited snapper-grouper species are also presented. We use these data to quantify expected movement patterns, diel activity, home range, and flux into and out of NTMRs, as well as to evaluate preferred reef habitat. We view these efforts as necessary precursors to improved NTMR designs (i.e. locations, size and configurations) that might contribute to sustaining regional coral reef-fish fisheries.

\section{METHODS}

Acoustic tracking. In March 2006, we deployed 25 VEMCO VR2 (VEMCO, www.vemco.com) hydrophone receivers in a grid array with 600 to $1000 \mathrm{~m}$ spacing in the RNA in Dry Tortugas National Park (Ault et al. 2007a; Fig. 1A,B,C). Receivers were strategically placed on either side of reserve boundaries to address cross-boundary movements. Receiver placement was guided by maps of bathymetry (10 m resolution). coral reef habitats (200 $\mathrm{m}$ resolution), and a comprehensive fishery-independent monitoring database to provide acoustic coverage over a representative range of depths and complex coral reef habitats (Ault et al. 2002, Franklin et al. 2003, Smith et al. 2011). Receivers were mounted $5 \mathrm{~m}$ above the seafloor to reduce benthic noise exposure, avoid signal blockage by habitat features (e.g. large blocks of coral reef), and maintain a superior listening angle for acoustically tagged reef fish (Voegeli \& Pincock 1996). Vinyl-coated wire and 3strand nylon lines reduced acoustic noise from the anchorages (e.g. Clements et al. 2005). Depths and benthic habitats were determined using shipboard multibeam and side-scan sonar, diver-based groundtruthing, airborne light detection and ranging (LIDAR), and photogrammetry methods (Franklin et al. 2003).

In January 2007, we expanded the footprint of the acoustic array with additional receivers and reconfigured the grid to better capture reserve cross-boundary movements over known reef habitats (Fig. 1C). Each omnidirectional VR2 hydrophone functioned as an underwater passive listening station, archiving unique acoustic transmission codes, dates, and times for all tagged fish passing within its detection range. Data were manually downloaded from receivers bimonthly between March 2006 and November 2007. The receiver array during 2006 provided partial coverage across approx $16 \mathrm{~km}^{2}$, while the 2007 array covered approx $30 \mathrm{~km}^{2}$. Average spacing between receivers was $832 \mathrm{~m}$. Receiver detection ranges were calibrated both spatially and temporally using several statistical assessment techniques that included (1) long-term detections at fixed distances, (2) boat- and diver-based mobile range-testing, and (3) tag and receiver validations in controlled field tests.

Fish were captured by hook-and-line over a range of key habitats proximal to the acoustic grid array. Selected fish in excellent physical condition and large 


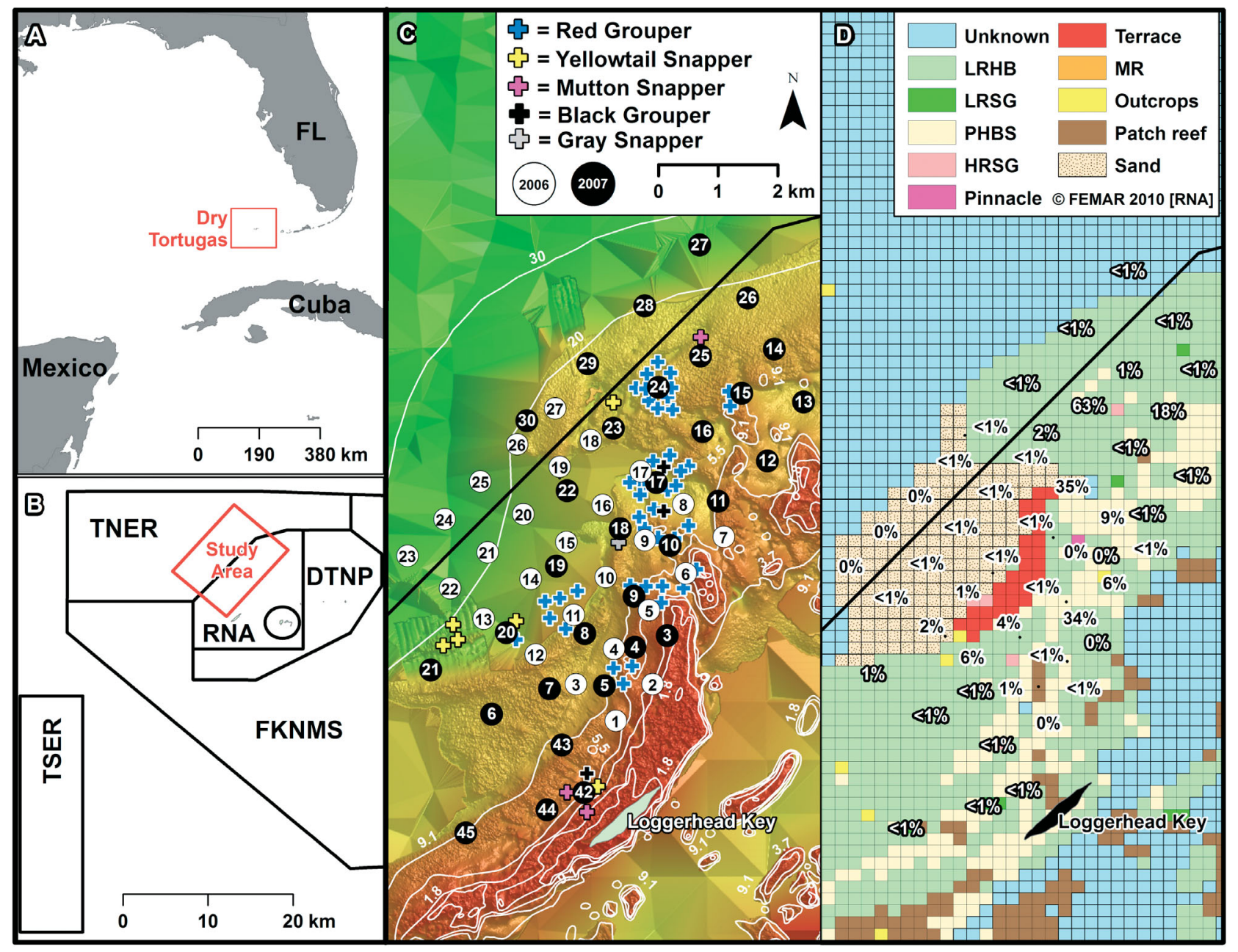

Fig. 1. Study area showing (A) Dry Tortugas, Florida; (B) study site relative to management zones, including fishable ('open') waters of Dry Tortugas National Park (DTNP) and Florida Keys National Marine Sanctuary (FKNMS), no-take Research Natural Area (RNA), no-take Tortugas North Ecological Reserve (TNER) and no-take Tortugas South Ecological Reserve (TSER); (C) hydroacoustic receiver placements in 2006 (white circles) and 2007 (black circles) overlain on bathymetry in RNA; and (D) percent detections by receiver for 2006 (white background) and 2007 (black background) relative to benthic habitats. LR: low relief; HB: hardbottom; SG: spur-and-groove; PHBS: patchy hardbottom in sand; HR: high relief; MR: medium relief

enough to accommodate an acoustic tag (e.g. $>45 \mathrm{~cm}$ total length, TL) received surgically implanted acoustic transmitters (VEMCO V16). Transmitters were inserted into the abdominal cavity using a procedure modified from Bolden (2001). All implanted tags weighed $24 \mathrm{~g}$ and were $58 \mathrm{~mm}$ long and $16 \mathrm{~mm}$ in diameter. Tags were configured with randomized transmission times (Table 1), reducing the likelihood of tag signal collisions with other tagged individuals within the array (Pincock \& Voegeli 2002). The relatively short delay times increased the probability of tag transmissions when in range of a specific receiver (Løkkeborg et al. 2002). Vicryl undyed
27 in chromic gut with $2 / 0$ curved needles was used to close incisions with 3 to 5 individual stitches. In 2006, Floy FD-94 T-bar tags (www.floytag.com) were inserted between the dorsal pterygiophores using a Mark II pistol grip gun. In 2007, Floy FIM-96 double-

Table 1. Specifications for $69 \mathrm{kHz}$ VEMCO V16 acoustic tags utilized in this study. Note $3 \mathrm{H}$ tags have higher transmission strength but shorter battery life

\begin{tabular}{|lcccccc|}
\hline Fish ID & Year & $\mathrm{N}$ & Type & $\begin{array}{c}\text { Power output } \\
(1 \mu \mathrm{pa} @ 1 \mathrm{~m})\end{array}$ & $\begin{array}{l}\text { Random } \\
\text { delay (s) }\end{array}$ & $\begin{array}{c}\text { Expected battery } \\
\text { life (d) }\end{array}$ \\
\hline $862-872$ & 2006 & 33 & $3 \mathrm{H}$ & 158 & $20-69$ & 56 \\
$170-194$ & 2006 & 23 & $3 \mathrm{H}$ & 158 & $30-79$ & 62 \\
$32-59$ & 2007 & 20 & $3 \mathrm{H}$ & 158 & $60-180$ & 130 \\
$873-884$ & 2007 & 12 & $4 \mathrm{H}$ & 153 & $20-69$ & 570 \\
\hline
\end{tabular}


barb anchor tags were inserted using a Floy 'jab stick'. Conventional tags were marked with a fish ID number; instructions to record the fish length, date, time, and location at time of capture; and a toll-free number and email address for reporting recaptures. Powder-form antibiotic Oxytetracyclin was applied to all punctures and incisions. Surgeries, which took from 2 to $5 \mathrm{~min}$, were performed in a large sterilized cooler containing continuously cycled seawater. All fish receiving an acoustic transmitter tag were released at their capture location after a short (from 5 to $25 \mathrm{~min}$ ) recovery period. Released fish were supervised during submergence to ensure that they escaped predators.

Data analysis. Prior to statistical analyses, VR2 receiver data were corrected for temporal drift using a linear correction formula that accounted for time of initialization, recorded time of download, and actual time of download (D. M. Webber, VEMCO, pers. comm.). Data were adjusted for daylight savings time. Any single, isolated detection occurring in a $24 \mathrm{~h}$ period was removed as potentially spurious (D. M. Webber, pers. comm.). Detections within $24 \mathrm{~h}$ of release were excluded to reduce the impacts of 'unnatural' post-surgical behaviors on analyses.

Activity centers: A position estimator employing weighted harmonic means was applied to the timespecific archived tag data from each fish, batched over 5 min and 120 min intervals. This modification of an approach by Simpfendorfer et al. (2002) allowed for creation of a time series of short term 'activity centers', calculated as the means of multiple receiver locations weighted by the estimated distance of the tag from each receiver during the specified batch interval. Weighting terms were derived from a logistic regression model fit to measurements of tag detection rate at 66 sites spaced at $150 \mathrm{~m}$ intervals, and from 0 to $850 \mathrm{~m}$ from any given receiver in the array. At each site, stationary acoustic tags were deployed $2 \mathrm{~m}$ above the seafloor for $\geq 90 \mathrm{~min}$. Detection rate was defined as detections divided by expected transmissions per unit time. Expected transmissions were standardized by tag ping rate (Table 1). The estimated logistic regression model was used to express the probability of tag detection subject to distance from a receiver while controlling for receiver depth, surrounding habitat rugosity, tidal flow, and wind-generated noise within a heterogeneous coral reef environment (Farmer 2009).

Wind-speed data were obtained from the National Data Buoy Center's C-MAN Station at 'Pulaski Shoal Light, FL' (PLSF1; 244 41' 36" N, 82 46' 24" W), located $12 \mathrm{~km}$ east of the receiver array (www.ndbc.noaa. gov). Extensive tag and receiver range-testing indicated that 5 min intervals were most appropriate for evaluating movement patterns, while 120 min intervals were optimal for evaluating presence-absence detec- tions. Overall mean activity centers for individual tagged fish were also computed using all post-screening tag detections. No formal statistical comparisons were made between species due to the substantial differences in samples sizes.

Distances moved and relative frequency of movement: Species mobility was evaluated using observed movement distance and the relative frequency of movement. Distances between consecutive 5 min position estimates were computed using custom software written in Java 6.10 (Sun Microsystems) and the Animal Movement Analysis Extension (AMAE) for ArcView (Hooge \& Eichenlaub 2000). Relative frequency of movement was determined as percentage of consecutive 5 min intervals with a detected change in position.

The likelihood of a tagged fish's movements being undetected outside the array was tested by examining the ratio of 120 min intervals with detections to the total possible number of 120 min intervals between the first and last detections. Use of $120 \mathrm{~min}$ intervals reduced the potentially confounding influences of extreme ambient noise (e.g. high winds, rainfall) and other types of signal interference.

Diel period and lunar brightness effects on movement patterns: Under the assumption that a moving reef fish would have increased detection rates and be detected by multiple receivers, 2 generalized linear mixed models (Pinheiro \& Bates 2000, Montgomery 2001, Zuur et al. 2009) were developed. The first examined daily detection rate dependent upon 'tag' as a random factor and the categorical variable 'diel period', consisting of Dawn (sunrise \pm 1 h), Day, Dusk (sunset \pm 1 h), and Night as a fixed factor. The second examined number of receivers recording detections dependent upon the same factors. To express overall differences in detection rates between diel periods, detection rates were standardized and averaged across individuals.

To examine the influence of lunar brightness on nocturnal movement, a generalized linear model was developed. This model examined nocturnal detection rate dependent upon 'tag' as a random factor and 'lunar period' as a fixed factor. Lunar period was expressed as a continuous wavelet function (Faraway 2006), ranging from 0 (new moon) to 1 (full moon). Model data were restricted to 'night' observations for individuals with detection periods longer than 1 mo. A quadratic regression was used to evaluate standardized detection rates dependent on lunar period.

Reserve boundary crossings: Fish were considered to have crossed an RNA boundary if subsequent 5 min activity centers were computed to be located on opposite sides of a boundary. Regression analysis was used to evaluate the relationship between distance of red grouper overall mean activity centers to RNA boundary and percent time spent outside the RNA. 
Home range utilization: Daily minimum convex polygon (MCP; MacDonald et al. 1980) home ranges for each fish were computed using a procedure in AMAE applied to $5 \mathrm{~min}$ activity centers. The results were area-observation curves, and if they suggested an asymptote, home range estimates were considered reliable following Laundré \& Keller (1984). Fish whose area-observation curves showed no asymptote were excluded from subsequent home range analyses. Home range size for fish with linear home ranges (i.e. detections at multiple receivers in a straight line) were estimated as the product of the detection area around the average midpoint between receivers $\left[\pi(832 / 2)^{2} \mathrm{~m}^{2}\right]$ and the number of receivers in the line. MCP home range estimates for 1 mutton snapper were computed, both including and excluding sites visited exclusively during presumed spawning runs. Exclusion of these sites appeared appropriate, given the sensitivity of the MCP method to peripheral observations; they did not appear to be part of the routine daily habitat for this individual (Burt 1943). Regression analysis was used to evaluate home range size, percent home range overlap, and distance between home range centers as a function of length and weight for red grouper.

Habitat utilization: Habitat types within $200 \times 200 \mathrm{~m}$ grid cells described by Franklin et al. (2003) were recategorized by coverage as contiguous (C), isolated (I) and spur-and-groove (SG), and by profile as low (L), medium (M) and high $(\mathrm{H})$. Regression analysis was used to evaluate percent home range overlap and distance between home range centers as a function of habitat coverage and profile.

Following methods presented in Winter \& Ross (1982) and Lowe et al. (2003), a habitat selection index was determined for each tagged fish as the ratio between the percentage of 5 min activity centers in a habitat grid cell and the percentage of $200 \times 200 \mathrm{~m}$ cells containing that identified habitat type within the fish's MCP home range. Habitat type was defined by a combination of coverage and profile as described above. Number of activity centers within each habitat type was computed for each fish using the Hawth's Tools 'Count Points within Polygons' extension for ArcGIS (Beyer 2004). Natural boundaries to movement were identified by examining dominant habitat types around receivers recording no detections.

\section{RESULTS}

\section{Acoustic tracking}

In 22 mo of study between March 2006 and November 2007, we acoustically tagged and tracked 58 ind. representing 5 snapper-grouper species (Table 2) and obtained nearly 2.5 million tag detections. Red grouper comprised $79 \%$ of the acoustically tagged fish. Larger red grouper were, however, generally absent in our tagging study, despite the fact that they comprise a significant portion of the population as shown in estimates made by diver-based visual census methods (Ault et al. 2007a, Smith et al. 2011). Sample sizes for other species were limited. These other species are presented in Table 2 (and elsewhere herein) for reference.

Time at liberty for tagged fish ranged from 2 to $280 \mathrm{~d}$, with an average of $102 \pm 7.6 \mathrm{~d}$ (mean \pm SE) for all species combined, $135 \pm 31$ d for black grouper $(n=3)$, $92 \mathrm{~d}$ for gray snapper ( $\mathrm{n}=1), 86 \pm 58 \mathrm{~d}$ for mutton snapper $(n=3), 111 \pm 2 d$ for red grouper $(n=45)$, and $83 \pm$ $9 \mathrm{~d}$ for yellowtail snapper $(\mathrm{n}=5)$. With the exception of yellowtail snapper, most tagged fish were tracked beyond their expected transmitter battery life (Table 2).

In 2006, 5 tagged red grouper were recaptured using hook and line -2 by researchers and 3 by sport fishers. Of these, 2 occurred within 25 d of initial capture and were re-released in good condition (ID nos. 865 and 866; Table 2). The other recaptures occurred between 42 and $142 \mathrm{~d}$ after initial capture and were also reported in good condition. About $60 \%$ of recaptures were made within $100 \mathrm{~m}$ of the original capturetagging site. Acoustically observed forays into nearby areas, conventional recaptures, and the apparent condition of recaptured fish alleviated our concerns of post-tagging mortality. No recaptures were reported following implementation of the RNA in January 2007, due presumably to reduced fishing effort in the RNA or to non-reporting.

\section{Movement patterns and distances moved}

Movement patterns exhibited by individual fish were varied, and percent detections varied widely between receivers (Fig. 1D). Most red grouper and the few tagged black grouper were detected within a core habitat around 1 or 2 hydrophones over the life of their acoustic tags, although rare to occasional detections at other locations did occur, especially for fish with overall mean activity centers closer to the core of the array. Similar detection patterns were often observed for individuals tagged at the same location (e.g. Fig. 2).

Relative frequency (Fig. 3A) and distance (Fig. 3B) of detected movements varied between species. Red grouper and yellowtail snapper moved moderate distances (from 700 to $900 \mathrm{~m}$ ) with moderate frequency. Observed movements by black grouper were relatively small and infrequent. Mutton snapper appeared to make short, frequent movements, although movements associated with spawning migrations were much broader in scale (Fig. 4). All observed move- 
Table 2. Data for fish fitted with acoustic transmitters. Dates follow mo/d/yr format; TL: total length; W: weight; Rec: no. of receivers detecting fish; HR: home range; NA: not applicable (no detection of tagged individual)

\begin{tabular}{|c|c|c|c|c|c|c|c|c|c|c|c|}
\hline Tag & Fish ID & $\begin{array}{l}\text { Common } \\
\text { name }\end{array}$ & $\begin{array}{c}\mathrm{TL} \\
(\mathrm{cm})\end{array}$ & $\begin{array}{c}\mathrm{W} \\
(\mathrm{kg})\end{array}$ & $\begin{array}{c}\text { Date } \\
\text { tagged }\end{array}$ & $\begin{array}{c}\text { Last } \\
\text { detect }\end{array}$ & Days & $\begin{array}{l}\text { Tag } \\
\text { life }\end{array}$ & Detects & Rec. & $\begin{array}{c}\mathrm{HR} \\
\left(\mathrm{km}^{2}\right)\end{array}$ \\
\hline \multicolumn{12}{|c|}{2006 configuration } \\
\hline $3 \mathrm{H}$ & 170 & Red grouper & 61 & 9 & 03/07/06 & 06/08/06 & 93 & 62 & 708 & 2 & Linear \\
\hline $3 \mathrm{H}$ & 172 & Red grouper & 49 & 4 & 03/07/06 & 03/10/06 & 3 & 62 & 471 & 8 & NA \\
\hline $3 \mathrm{H}$ & 171 & Red grouper & 60 & 6.5 & 03/07/06 & 06/13/06 & 98 & 62 & 2359 & 4 & 0.64 \\
\hline $3 \mathrm{H}$ & 173 & Red grouper & 49 & 4 & 03/07/06 & 06/07/06 & 92 & 62 & 613 & 5 & 1.28 \\
\hline $3 \mathrm{H}$ & 174 & Black grouper & 50 & 5.5 & 03/07/06 & 06/06/06 & 91 & 62 & 11466 & 4 & 0.39 \\
\hline $3 \mathrm{H}$ & 175 & Red grouper & 53 & 6 & 03/07/06 & 06/11/06 & 96 & 62 & 5190 & 2 & Linear \\
\hline $3 \mathrm{H}$ & 176 & Red grouper & 55 & 6.5 & 03/07/06 & 06/08/06 & 93 & 62 & 4512 & 4 & 0.64 \\
\hline $3 \mathrm{H}$ & 177 & Red grouper & 50 & 4.5 & 03/07/06 & 06/04/06 & 89 & 62 & 373 & 2 & Linear \\
\hline $3 \mathrm{H}$ & 178 & Red grouper & 65 & 10 & 03/07/06 & 06/05/06 & 90 & 62 & 2466 & 2 & Linear \\
\hline $3 \mathrm{H}$ & 179 & Red grouper & 57 & 6 & 03/27/06 & $04 / 19 / 06$ & 23 & 62 & 229 & 14 & NA \\
\hline $3 \mathrm{H}$ & 180 & Red grouper & 55 & 6 & 03/27/06 & 05/06/06 & 40 & 62 & 382 & 5 & 3.19 \\
\hline $3 \mathrm{H}$ & 181 & Red grouper & 49 & 4 & 03/27/06 & 04/09/06 & 13 & 62 & 880 & 9 & NA \\
\hline $3 \mathrm{H}$ & 182 & Yellowtail snapper & 52 & 2.5 & 03/28/06 & 04/23/06 & 26 & 62 & 39374 & 9 & 2.57 \\
\hline $3 \mathrm{H}$ & 183 & Red grouper & 48 & 4.5 & 03/28/06 & 07/04/06 & 98 & 62 & 8491 & 3 & 3.22 \\
\hline $3 \mathrm{H}$ & $184^{\mathrm{a}}$ & Red grouper & 55 & 6.5 & 03/27/06 & 05/09/06 & 43 & 62 & 4915 & 7 & 1.91 \\
\hline $3 \mathrm{H}$ & $185^{\mathrm{a}}$ & Red grouper & 55 & 5 & 03/27/06 & 05/09/06 & 43 & 62 & 8895 & 7 & 1.90 \\
\hline $3 \mathrm{H}$ & 186 & Red grouper & 51 & 6 & 03/27/06 & 06/26/06 & 91 & 62 & 12077 & 8 & 3.49 \\
\hline $3 \mathrm{H}$ & 187 & Red grouper & 50 & 4.5 & 03/27/06 & 06/27/06 & 92 & 62 & 4806 & 8 & 1.89 \\
\hline $3 \mathrm{H}$ & 189 & Red grouper & 59 & 8 & 03/07/06 & 06/09/06 & 94 & 62 & 28035 & 1 & Single \\
\hline $3 \mathrm{H}$ & 190 & Red grouper & 62 & 9 & 03/06/06 & 06/15/06 & 101 & 62 & 55092 & 2 & Linear \\
\hline $3 \mathrm{H}$ & 191 & Red grouper & 51 & 4 & 03/06/06 & 06/07/06 & 93 & 62 & 36324 & 4 & 0.63 \\
\hline $3 \mathrm{H}$ & 194 & Red grouper & 54 & 6.5 & 03/06/06 & 06/08/06 & 94 & 62 & 12928 & 4 & 1.55 \\
\hline $3 \mathrm{H}$ & $862^{\mathrm{a}}$ & Red grouper & 54 & 4.5 & 03/06/06 & 05/31/06 & 86 & 56 & 73704 & 3 & NA \\
\hline $3 \mathrm{H}$ & 863 & Red grouper & 51 & 6.5 & 03/05/06 & 06/08/06 & 95 & 56 & 6728 & 3 & 0.31 \\
\hline $3 \mathrm{H}$ & 864 & Red grouper & 55 & 6 & 03/06/06 & 06/06/06 & 92 & 56 & 44890 & 2 & Linear \\
\hline $3 \mathrm{H}$ & $865^{\mathrm{a}}$ & Red grouper & 56 & 8 & 03/05/06 & 04/07/06 & 33 & 56 & 14616 & 6 & 1.28 \\
\hline $3 \mathrm{H}$ & $866^{\mathrm{a}}$ & Red grouper & 53 & 5 & 03/06/06 & 05/11/06 & 66 & 56 & 426 & 2 & Linear \\
\hline $3 \mathrm{H}$ & 867 & Red grouper & 55 & 5.5 & 03/05/06 & $06 / 02 / 06$ & 89 & 56 & 42058 & 4 & 0.49 \\
\hline $3 \mathrm{H}$ & 868 & Red grouper & 49 & 4.5 & 03/05/06 & 06/01/06 & 88 & 56 & 24533 & 2 & Linear \\
\hline $3 \mathrm{H}$ & 869 & Red grouper & 60 & - & 03/06/06 & 06/01/06 & 87 & 56 & 21703 & 2 & Linear \\
\hline $3 \mathrm{H}$ & 870 & Red grouper & 45 & 2.5 & 03/05/06 & 03/30/06 & 25 & 56 & 2530 & 7 & 2.20 \\
\hline $3 \mathrm{H}$ & 871 & Red grouper & 57 & 8 & 03/05/06 & 05/20/06 & 76 & 56 & 402 & 2 & Linear \\
\hline $3 \mathrm{H}$ & 872 & Red grouper & 53 & 4.5 & 03/05/06 & 05/23/06 & 79 & 56 & 70316 & 4 & 0.49 \\
\hline \multicolumn{12}{|c|}{2007 configuration } \\
\hline $3 \mathrm{H}$ & 43 & Black grouper & 74.9 & 6.6 & $01 / 07 / 07$ & $07 / 05 / 07$ & 179 & 130 & 72644 & 6 & 2.48 \\
\hline $3 \mathrm{H}$ & 35 & Black grouper & 57 & 4.5 & $10 / 09 / 07$ & NA & 0 & 130 & 0 & 0 & - \\
\hline $3 \mathrm{H}$ & 53 & Mutton snapper & 70 & 5.4 & $04 / 25 / 07$ & $10 / 10 / 07$ & 168 & 130 & 21805 & 18 & 7.64 \\
\hline $3 \mathrm{H}$ & 40 & Mutton snapper & 53 & 4.5 & $04 / 25 / 07$ & NA & 0 & 130 & 0 & 0 & - \\
\hline $3 \mathrm{H}$ & 50 & Mutton snapper & 43 & 2.5 & $10 / 09 / 07$ & $10 / 13 / 07$ & 4 & 130 & 183 & 6 & NA \\
\hline $3 \mathrm{H}$ & 52 & Mutton snapper & 49 & 2 & $10 / 09 / 07$ & NA & 0 & 130 & 0 & 0 & - \\
\hline $3 \mathrm{H}$ & 36 & Red grouper & 63.5 & 3.6 & $01 / 07 / 07$ & $01 / 25 / 07$ & 18 & 130 & 2051 & 15 & NA \\
\hline $3 \mathrm{H}$ & 37 & Red grouper & 47 & 1.4 & $01 / 07 / 07$ & 07/05/07 & 179 & 130 & 64672 & 3 & 0.47 \\
\hline $3 \mathrm{H}$ & 41 & Red grouper & 47 & 1.1 & $01 / 07 / 07$ & 07/05/07 & 179 & 130 & 75732 & 3 & 0.44 \\
\hline $3 \mathrm{H}$ & 42 & Red grouper & 48.3 & 1.8 & $01 / 07 / 07$ & $07 / 05 / 07$ & 179 & 130 & 21823 & 4 & 0.93 \\
\hline $3 \mathrm{H}$ & 47 & Red grouper & 48.3 & 1.8 & $01 / 07 / 07$ & 01/18/07 & 11 & 130 & 1534 & 17 & NA \\
\hline $3 \mathrm{H}$ & 51 & Red grouper & 66 & 5.4 & $02 / 27 / 07$ & 08/03/07 & 157 & 130 & 12329 & 6 & 1.95 \\
\hline $3 \mathrm{H}$ & 55 & Yellowtail snapper & 55 & 1.8 & $04 / 24 / 07$ & 09/24/07 & 153 & 130 & 10566 & 6 & 10.72 \\
\hline $3 \mathrm{H}$ & 57 & Yellowtail snapper & 52 & 1.4 & 07/11/07 & $10 / 11 / 07$ & 92 & 130 & 31804 & 7 & 4.65 \\
\hline $3 \mathrm{H}$ & 58 & Yellowtail snapper & 48 & 0.9 & $04 / 24 / 07$ & 07/01/07 & 68 & 130 & 2238 & 3 & 0.75 \\
\hline $3 \mathrm{H}$ & 59 & Yellowtail snapper & 52 & 0.9 & $04 / 24 / 07$ & 07/10/07 & 77 & 130 & 4791 & 5 & 2.17 \\
\hline $4 \mathrm{H}$ & 882 & Gray snapper & 54 & 2.7 & 07/10/07 & 10/10/07 & 92 & 570 & 25243 & 6 & NA \\
\hline $4 \mathrm{H}$ & 873 & Red grouper & 48.3 & 1.8 & $01 / 04 / 07$ & $10 / 11 / 07$ & 280 & 570 & 199933 & 2 & 6.44 \\
\hline $4 \mathrm{H}$ & 874 & Red grouper & 59.7 & 2.9 & $01 / 05 / 07$ & $10 / 10 / 07$ & 278 & 570 & 313237 & 5 & 1.40 \\
\hline $4 \mathrm{H}$ & 875 & Red grouper & 52.1 & 2 & $01 / 04 / 07$ & $10 / 11 / 07$ & 280 & 570 & 205442 & 5 & 1.68 \\
\hline $4 \mathrm{H}$ & 877 & Red grouper & 57.2 & 2.7 & $01 / 04 / 07$ & $10 / 11 / 07$ & 280 & 570 & 124104 & 4 & 0.83 \\
\hline $4 \mathrm{H}$ & 878 & Red grouper & 48.3 & 1.8 & $01 / 04 / 07$ & 02/17/07 & 44 & 570 & 21144 & 9 & 5.76 \\
\hline $4 \mathrm{H}$ & 880 & Red grouper & 48.9 & 1.8 & $01 / 04 / 07$ & 09/30/07 & 269 & 570 & 35439 & 3 & 2.59 \\
\hline $4 \mathrm{H}$ & 881 & Red grouper & 49.5 & 1.8 & $01 / 04 / 07$ & $10 / 11 / 07$ & 280 & 570 & 261025 & 7 & 9.17 \\
\hline $4 \mathrm{H}$ & 884 & Red grouper & 53.3 & 2 & $01 / 04 / 07$ & $10 / 11 / 07$ & 280 & 570 & 272798 & 5 & 1.68 \\
\hline
\end{tabular}



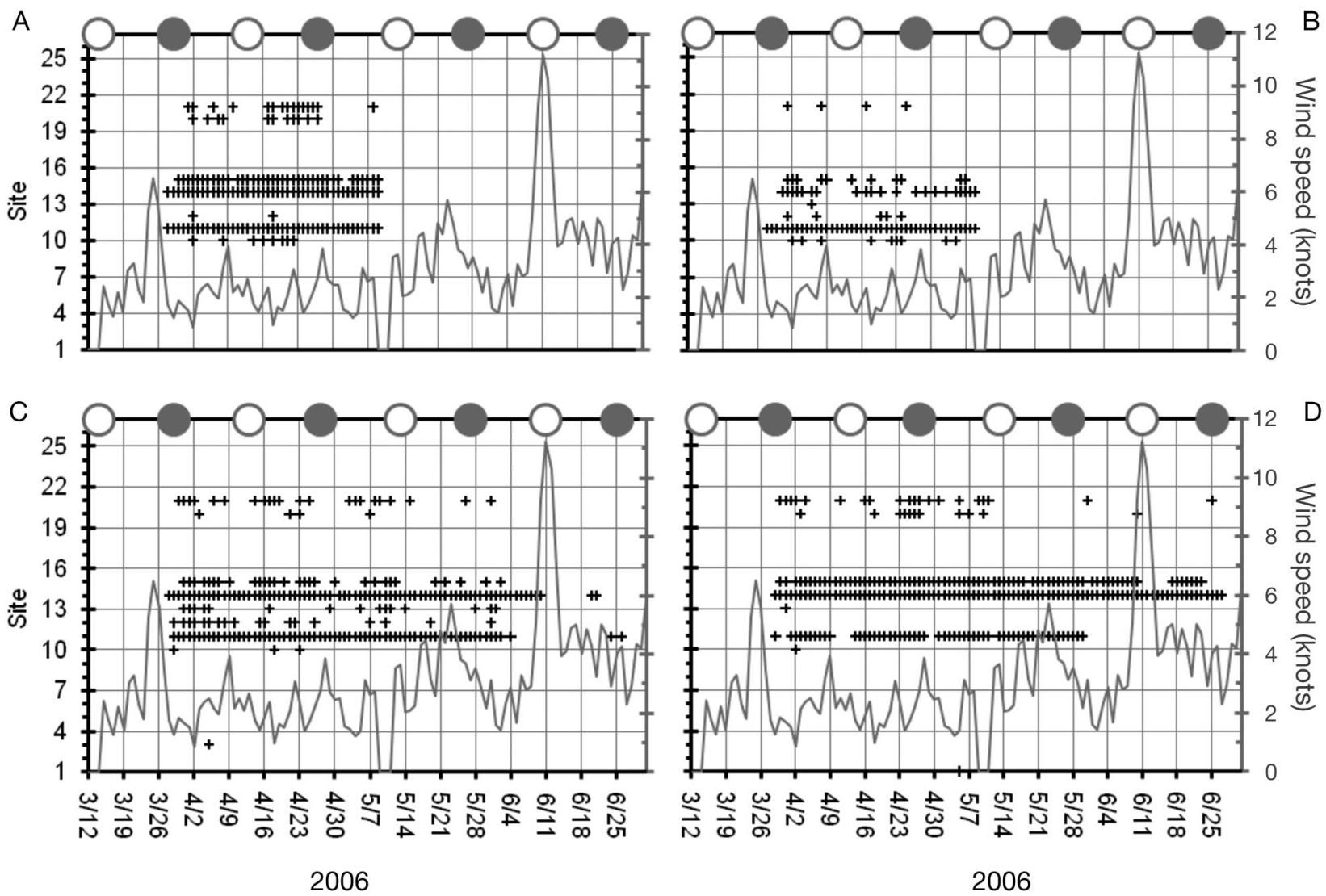

Fig. 2. Epinephelus morio. Detections in 2006 by site for individual (A) no. 184, (B) no. 185, (C) no. 186, and (D) no. 187, all tagged at the same location on the morning of March 27, 2006. Note the overlap in detections between individuals, suggesting similar space use and movement patterns. Wind speed and lunar cycle are co-plotted, with open circles denoting full moons. The passage of tropical storm Alberto is denoted, June 10-13, and appears to correspond with a brief lack of detections for fish no. 186. Fish nos. 184 and 185 were both captured and killed on May 9, 2006, by a charter boat captain

ments by the gray snapper exceeded $1000 \mathrm{~m}$, and appeared to be associated with a nocturnal migration beyond the array.

Movements beyond the scope of the array would be undetected and could confound computations of movement frequency. Percent time fish were detected in the acoustic array ranged from 47 to $87 \%$ (Fig. 3C). These long-term detection rates suggested that most black grouper, red grouper, and yellowtail snapper did not move beyond the scope of the array. Fish captured near the center of the acoustic array (e.g. where edge effects would be minimal) were detected in $>10 \%$ of 5 min batching intervals.

\section{Diel period and lunar brightness effects on movement patterns}

Red grouper detection rate varied by time of day (Fig. 3D, Table 3), with Day $(29.4 \%)>$ Dawn $(28.6 \%)>$ Dusk $(27.7 \%)>$ Night $(24.1 \%)$. For red grouper, re- ceivers recording detections differed significantly (Table 3) by diel period: Day (1.32) > Night (1.27) > Dusk (0.87) > Dawn (0.80). Lunar period significantly influenced detection rates for red grouper (Table 3), quadratic regression indicating significantly higher detection rates $\left(F_{2,38}=7.9, \mathrm{p}<0.005\right)$ associated with moderately bright lunar periods (Fig. 5). For yellowtail snapper, number of detecting receivers differed significantly (Table 3 ) by diel period: Day (1.71) > Night (1.39) > Dusk (0.92) $\approx$ Dawn (0.91). Low detection rates at night may be attributable to increased ambient noise rather than to sheltering activity or reduced movements (McCauley 1994).

\section{Boundary crossings}

Detected flux rates across reserve boundaries varied. In 2006, only 2 of $31(6 \%)$ red grouper were detected moving across RNA boundaries. However, in 2007, after reconfiguring the acoustic array to cover more 

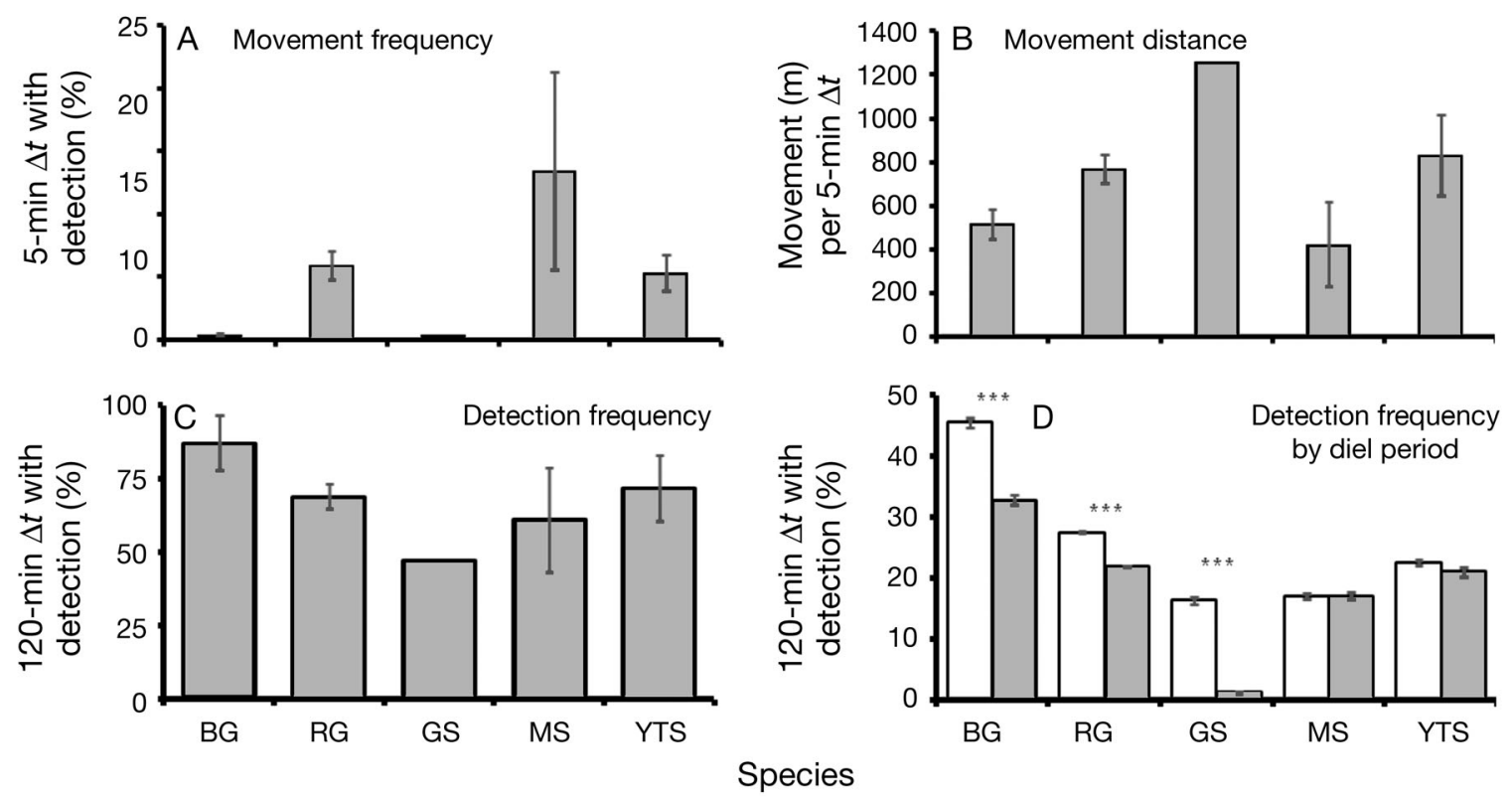

Fig. 3. Differences in (A) relative frequency of movement per 5 min interval ( $\Delta t$ ), (B) mean non-zero distances moved per 5 min $\Delta t$, (C) mean percentage of $120 \mathrm{~min} \Delta t$ with detections, and (D) mean percentage of $120 \mathrm{~min} \Delta t$ with detections at night (gray bars) and day (white bars), by species. BG: black grouper; RG: red grouper; GS: gray snapper; MS: mutton snapper; YTS: yellowtail snapper. Error bars: SE; asterisks: significant differences at $\mathrm{p}<0.001$

Table 3. Summary statistics for tests of diel and lunar movement patterns. Time: time of day

\begin{tabular}{|lclccc|}
\hline \multirow{2}{*}{ Species } & Variable & Factor & $F$ & df & p \\
\hline Red grouper & Detection & Time & 10.9 & 3,187 & $<0.001$ \\
& rate & Tag & 86.4 & 44,132 & $<0.001$ \\
& & Time $\times$ Tag & 12.2 & 132,18388 & $<0.001$ \\
& Detecting & Time & 63.2 & 3,160 & $<0.001$ \\
& receivers & Tag & 7.6 & 44,132 & $<0.001$ \\
& & Time $\times$ Tag & 23.3 & 132,18388 & $<0.001$ \\
& Detection & Lunar stage & 4.4 & 40,3685 & $<0.001$ \\
& rate & Tag & 300.1 & 38,3907 & $<0.001$ \\
Yellowtail & & Lunar stage $\times$ Tag & 0.5 & 1379,3127 & $>0.05$ \\
snapper & Detection & Time & 2.7 & 3,14 & $>0.05$ \\
& rate & Tag & 174.6 & 4,12 & $<0.001$ \\
& & Time $\times$ Tag & 4.7 & 12,1520 & $<0.001$ \\
& Detecting & Time & 36.2 & 3,15 & $<0.001$ \\
& receivers & Tag & 65.9 & 4,12 & $<0.001$ \\
& & Time $\times$ Tag & 2.9 & 12,1520 & $<0.001$ \\
& Detection & Lunar stage & 1.5 & 39,136 & $>0.05$ \\
& rate & Tag & 29.6 & 3,151 & $<0.001$ \\
& & Lunar stage $\times$ Tag & 1.3 & 106,211 & $<0.05$ \\
\hline
\end{tabular}

crossing the boundary 10 times, spending $3.4 \%$ of its time in TNER. Only 1 of 2 mutton snapper was detected moving across reserve boundaries, but it did so 702 times, spending $9 \%$ of its time in TNER. For red grouper, logtransformed distance of overall mean activity center from RNA boundary explained $40 \%$ of the variability in percent time spent outside the RNA $\left(\beta=-0.64, F_{1,43}=29.5, \mathrm{p}<0.001\right)$.

\section{Home range utilization}

Most acoustically tagged grouper and snapper utilized home ranges contained within the bounds of the acoustic array (Table 4, Fig. 6). Ten red grouper were detected at only 1 or 2 receivers. Inclusion of linear home ranges reduced the red grouper home range estimate from

reef habitats (see Fig. 1C), 4 of 14 (29\%) red grouper were detected moving across RNA boundaries into Tortugas North Ecological Reserve (TNER). No black grouper were detected moving across reserve boundaries in either year. Only 1 of 5 yellowtail snapper moved across the reserve boundary; this fish crossed the boundary 62 times, but spent less than $2 \%$ of its total time in TNER. The one gray snapper was detected
$2.09 \pm 0.39 \mathrm{~km}^{2}(\mathrm{n}=28)$ to $1.30 \pm 0.16 \mathrm{~km}^{2}(\mathrm{n}=38)$. No significant relationships were found between red grouper length $\left(F_{1,31}=0.05, \mathrm{p}>0.05\right)$ or weight $\left(F_{1,31}=0.14, \mathrm{p}>\right.$ 0.05 ) and home range size.

High levels of MCP home range overlap (43.01 \pm $7.12 \%$ ) were observed among red grouper captured at the same location (mean $=0.54 \pm 0.13 \mathrm{~km}^{2} ; \mathrm{n}=25$ ). Percent overlap between red grouper MCP home ranges 


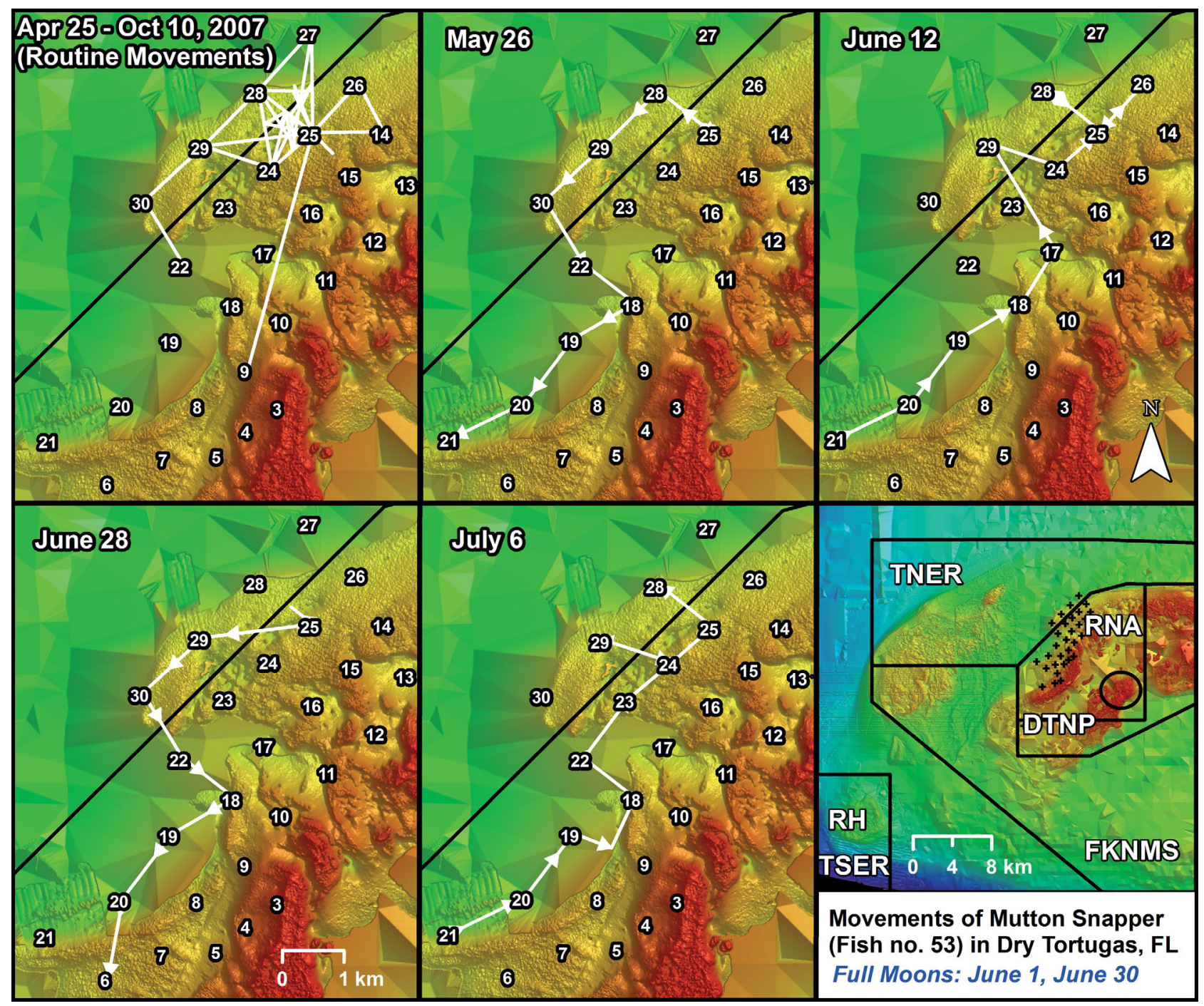

Fig. 4. Lutjanus analis. Routine daily movements (upper left) and possible spawning migration movements (May 26, June 12, June 28, and July 6) by fish no. 53 (70 cm TL, $5.4 \mathrm{~kg}$ ). Fish no. 53 was tagged April 25, 2007 and tracked for $168 \mathrm{~d}$. Lower right panel illustrates inferred broad scale movements across multiple management areas during periods with no detections (May 27 to June 13, June 13 to July 6). These absences followed unique directional movements to the southwest, corresponding with full moons, coinciding with timing of a known spawning aggregation at Riley's Hump (RH) in Tortugas South Ecological Reserve (TSER), and were followed by unique directional movements back into the array from the southwest. FKNMS: Florida Keys National Marine Sanctuary; DTNP: Dry Tortugas National Park; RNA: Research Natural Area; TNER: Tortugas North Ecological Reserve. See Fig. 1 for details of receiver placements

increased significantly with increasing fish TL $(\beta=$ $2.88, F_{1,48}=5.4$, adj. $\left.\mathrm{r}^{2}=0.08, \mathrm{p}<0.05\right)$ and weight $(\beta=$ $23.41, F_{1,48}=10.2$, adj. $\left.\mathrm{r}^{2}=0.16, \mathrm{p}<0.05\right)$.

Habitat was a significant controlling factor for percent overlap (Table 5). Red grouper in contiguous habitat had significantly lower MCP home range overlap than red grouper in isolated habitat and spur-andgroove habitat. Red grouper in high-relief habitats had significantly higher MCP home range overlap than red grouper in low-relief habitats. Mean distance between home range centers for red grouper caught at the same time and location $(\mathrm{n}=25)$ was $611.36 \pm 179.53 \mathrm{~m}$. No significant relationships were detected between distance between home range centers and TL, weight, dominant habitat type, or dominant level of relief.

\section{Habitat utilization}

Red grouper underutilized low-relief, isolated reef structures relative to their availability, showing preference for high-relief, contiguous structures (Fig. 7). Yel- 
Table 4. Minimum convex polygon (MCP) home range estimates for acoustically tagged fish, and time required to obtain asymptotic MCP home range estimate (mean $\pm \mathrm{SE}$ ). -: no asymptote was reached, and no home range estimate could be generated following the procedures described in 'Methods'

\begin{tabular}{|c|c|c|c|c|}
\hline Common name & Species & $\mathrm{n}^{\mathrm{a}}$ & Time to asymptote (d) & MCP home range $\left(\mathrm{km}^{2}\right)$ \\
\hline Black grouper & Mycteroperca bonaci & 2 of $3(66 \%)$ & $46.5 \pm 0.5$ & $1.44 \pm 1.04$ \\
\hline Red grouper & Epinephelus morio & 28 of $45(62 \%)$ & $38.5 \pm 6.4$ & $2.09 \pm 0.39$ \\
\hline Gray snapper & Lutjanus griseus & 0 of $1(0 \%)$ & - & - \\
\hline Mutton snapper & Lutjanus analis & 1 of $3^{b}(33 \%)$ & $72^{\mathrm{c}}$ & $7.64^{\mathrm{b}}$ \\
\hline Yellowtail snapper & Ocyurus chrysurus & 4 of $5(80 \%)$ & $47.6 \pm 28.8$ & $4.17 \pm 1.75$ \\
\hline
\end{tabular}

Table 5. Epinephelus morio. Percent minimum convex polygon (MCP) home range overlap for acoustically tagged red grouper

\begin{tabular}{|lrccccc|}
\hline \multirow{2}{*}{ Habitat } & \multicolumn{7}{c|}{$\begin{array}{c}\text { MCP home range overlap } \\
\text { n }\end{array}$} & Mean (\%) & SE (\%) & & df & $\mathrm{p}$ \\
& & & & & \\
\hline Contiguous & 31 & 38.0 & 5.4 & - & - & - \\
Isolated & 7 & 90.1 & 5.7 & -4.42 & 36 & $<0.001$ \\
Spur-and-groove & 2 & 97.4 & 2.6 & -2.74 & 31 & $<0.05$ \\
High-relief & 6 & 87.3 & 6.5 & - & - & - \\
Low-relief & 34 & 43.5 & 5.8 & 3.09 & 38 & $<0.01$ \\
\hline
\end{tabular}

lowtail snapper appeared to avoid highrelief, isolated habitats in favor of lowrelief, contiguous reef (Fig. 7).

Broad, deep, continuous expanses of sand appeared to be a natural boundary to movement for reef fish. In 2006, receivers at sites A23, A24, and A25 were located in sand habitats off the reef shelf (see Fig. 1A). These 3 receivers were the only receivers in either phase of the study never to register reef fish detections (see Fig. 1B).

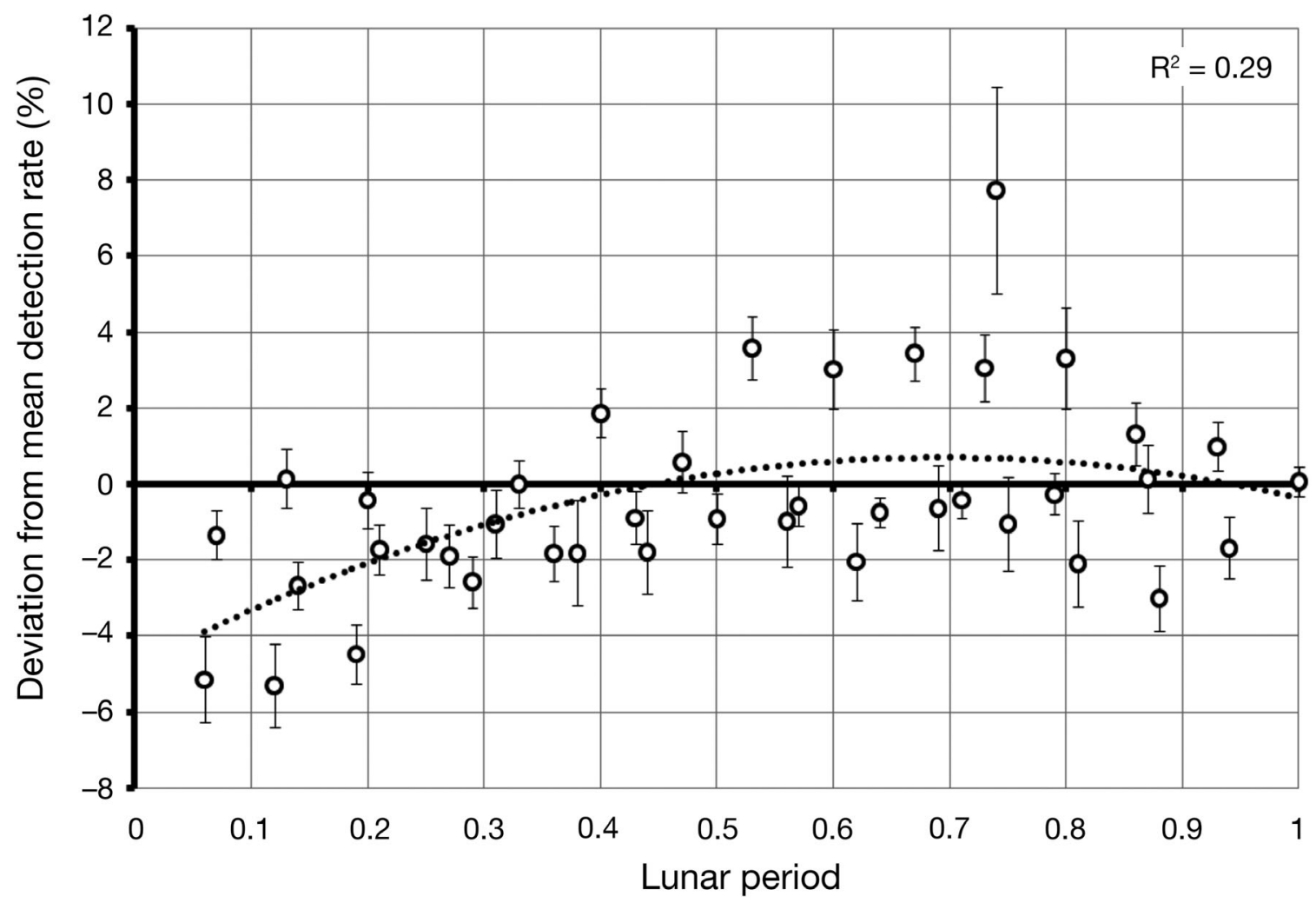

Fig. 5. Epinephelus morio. Quadratic regression fit to mean deviations (across individuals) of detection rates of tagged individuals ( $\mathrm{n}=39$ ) per lunar interval (a nighttime observation of percent detections within a time interval, i.e. batching interval), relative to individual mean detection rates across lunar periods (stage of the moon from 0 [new moon] to 1 [full moon]). Error bars: SE 


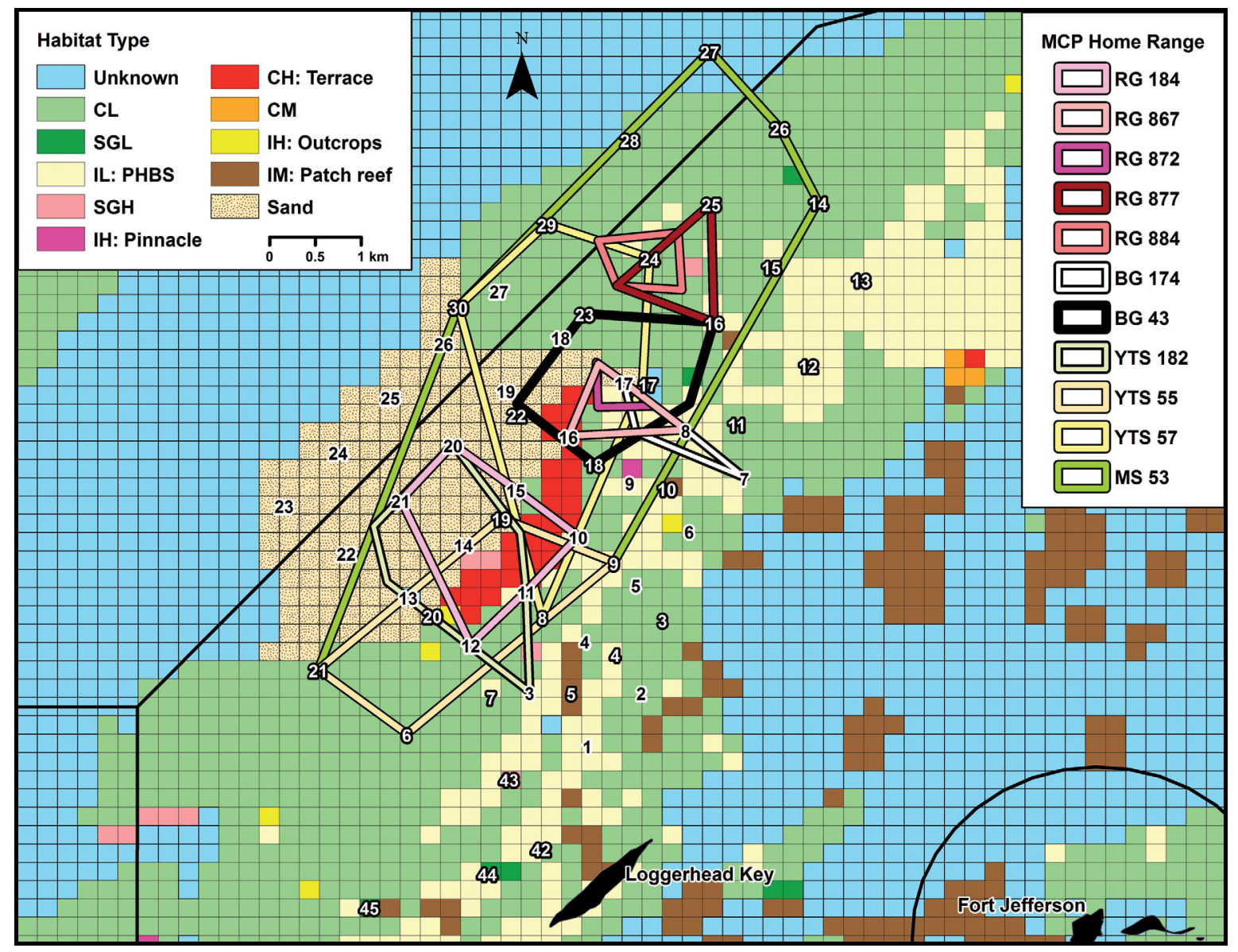

Fig. 6. Examples of minimum convex polygon (MCP) home range areas computed from 5 min harmonic mean positioning estimates for tracked black grouper (BG), mutton snapper (MS), red grouper (RG), and yellowtail snapper (YTS). MCPs are depicted relative to habitat type and 2006 (black numbers) and 2007 (white numbers) receiver positions. C: contiguous; I: isolated; SG: spur-and-groove; H: high; M: medium; L: low relief; HB: hard bottom; PHBS: patchy HB in sand

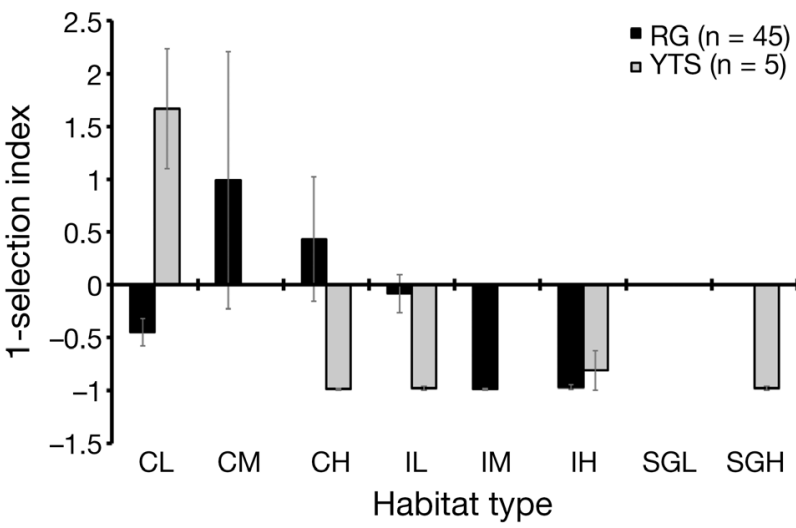

Fig. 7. Mean habitat selection index values $( \pm \mathrm{SE})$ for red grouper (RG) and yellowtail snapper (YTS), depicted as deviation from 1. Positive values indicate habitats utilized above their percent availability within the MCP home range; negative values indicate habitats utilized below percent availability. Habitat types categorized by coverage (C: contiguous; I: isolated; SG: spur-and-groove) and profile (L: low; M: medium; H: high)

\section{DISCUSSION}

For NTMRs to provide sufficient buffering against exploitation, Barrett (1995) recommended their diameter be, at minimum, an order of magnitude larger than the daily movements of the targeted organisms. Mean home range sizes for the 5 snapper-grouper species studied were from 1 to 2 orders of magnitude smaller than the Tortugas NTMRs. Assuming our tagged organisms were representative of these stocks, the NTMRs of the Tortugas may afford significant protection from exploitation for the species and life stages we evaluated. Future tagging studies should increase the sample sizes and size ranges of fish tracked, which would help verify our findings and the range of their interpretation.

Although most fish remained within range of a few receivers throughout their tracking period, occasional NTMR boundary crossings were detected. All observed boundary crossings by reef fish occurred where NTMR boundaries overlie contiguous coral reef habitats. 
Boundary crossings for tagged snappers appeared to be associated with daily or spawning migrations. Fish no. 53 was a sexually mature (Claro 1981) mutton snapper. This fish had 2 extended absences (16 d and $8 \mathrm{~d}$ ) from the array during its $168 \mathrm{~d}$ tracking period. These departures roughly corresponded to the full moon and were characterized by a sequence of detections at receivers that were never revisited at any other time (see Fig. 4). The direction of travel and the presence of a documented spawning aggregation of mutton snapper over Riley's Hump in the TSER during full moons during the period May to July suggest that these movements were 2 spawning migrations (Burton et al. 2005). Two sexually mature yellowtail snapper (fish nos. 58 and 59) appeared to depart the array during July. Lindeman et al. (2000) suggested that this species spawns between May and June in the lower Florida Keys and possibly at Riley's Hump in the TSER. Interestingly, a larger, concurrently tagged yellowtail snapper (fish no. 55) showed similar patterns of daily space use, but was detected every day for $153 \mathrm{~d}$. It is unclear whether the disappearances of fish nos. 58 and 59 corresponded to spawning movements; further research into the importance of the Tortugas NTMRs for spawning yellowtail snapper is recommended. Consistent with observations by Moe (1972) and Luo et al. (2009), a tagged gray snapper made routine nocturnal migrations between site B19 (see Fig. 1C) and presumed foraging habitats west of the array, possibly outside the RNA.

In addition to these detected departures from the RNA, there may have been undetected movements out of the array. For example, some red grouper (11\%) were detected for fewer than $25 \mathrm{~d}$, as compared to the mean tracking period for the species of $102 \mathrm{~d}$. A greater amberjack Seriola dumerili tagged during this study was detected briefly in the array and then subsequently recaptured about 2.5 yr later off the Yucatán coast near Cancún. The limited scope of our acoustic array relative to the scale of the RNA makes it difficult to empirically quantify the rate of spillover. Mixed technologies, such as combination of acoustic and satellite tagging, may be required to fully resolve the rate and impacts of spillover. Low rates of spillover would reduce the rate of stock recovery but may increase fisheries yields, especially when fishing effort redistributes along reserve boundaries (Kellner et al. 2007, Farmer 2009). High rates of spillover might critically compromise NTMR protection (Kellner et al. 2007, Farmer 2009).

Although NTMR protection appears substantial for our tagged fish, the movements we observed may not be representative of all size classes for the grouper and snapper observed. Several studies have suggested that smaller, less competitive individuals are more likely to make large daily movements (Young 1963, Kramer \&
Chapman 1999, Bell \& Kramer 2000). For many reef fish species, migration toward deeper (>36 m) habitats begins near the onset of sexual maturity (Lindeman et al. 2000). All fish in this study were captured in shallow habitats $(<36 \mathrm{~m})$. All tagged red grouper (from 45 to $66 \mathrm{~cm}$ TL) were likely females (Collins et al. 2002) near sexual maturity (Fitzhugh et al. 2006). It is unclear if red grouper within the RNA would emigrate to spawn, since red grouper spawn in depths $>25 \mathrm{~m}$ and do not form aggregations (Coleman et al. 1996). No spawning migrations were observed among the tagged black grouper, although winter (January to April) spawning aggregations in Florida (Eklund et al. 2000) and Belize (February to March; Paz \& Sedberry 2007) have been reported. It is unlikely any of our 3 tagged black grouper were sexually mature (Crabtree \& Bullock 1998, Ault et al. 2005b, 2007b). Sexually mature fish might leave the RNA in search of deeper habitats or spawning aggregations.

The spatial arrangement of resources within fragmented landscapes has significant structuring effects upon space use and behavior (MacDonald 1983, Atwood \& Weeks 2003). Although we failed to detect differences in overall home range size by habitat, we did find greater overlap in red grouper home ranges in isolated $(90 \%)$ as compared to contiguous (38\%) habitats. As isolated reefs represent compressed habitats, it is not surprising that home range overlap would be higher due to space limitations. Home range overlap may be viewed as a proxy for territoriality (Nemtzov 1997). High levels of overlap in MCP home ranges were observed for red grouper tagged in the same location. These observations suggest that if red grouper are territorial fish, their defended home ranges (Schenkel 1966) must be smaller than the area covered by a single receiver in this study. However, the threshold biomass to induce density-dependent emigration in this species is still unclear.

Low-profile contiguous reefs are the most common habitats in the Dry Tortugas (Ault et al. 2006a) and contain the highest densities of red grouper (Smith et al. 2011). Tagged red grouper underutilized isolated habitats relative to their availability. Food-value theory (Stenger 1958, Wilson 1975) and cost-benefit analyses (Brown 1964) have suggested that resource availability plays a major role in determining animal home range size and overlap. High-profile coral reef habitats provide higher prey densities for red grouper (Ault et al. 2007a), and likely contain more locations for shelter. High-quality habitats may allow animals to maximize energy intake in a small undefended space, whereas larger defended ranges may be advantageous in moderate-quality habitats (Carpenter \& MacMillen 1976). Red grouper home range overlap was higher in highprofile habitats than in low-profile habitats. 


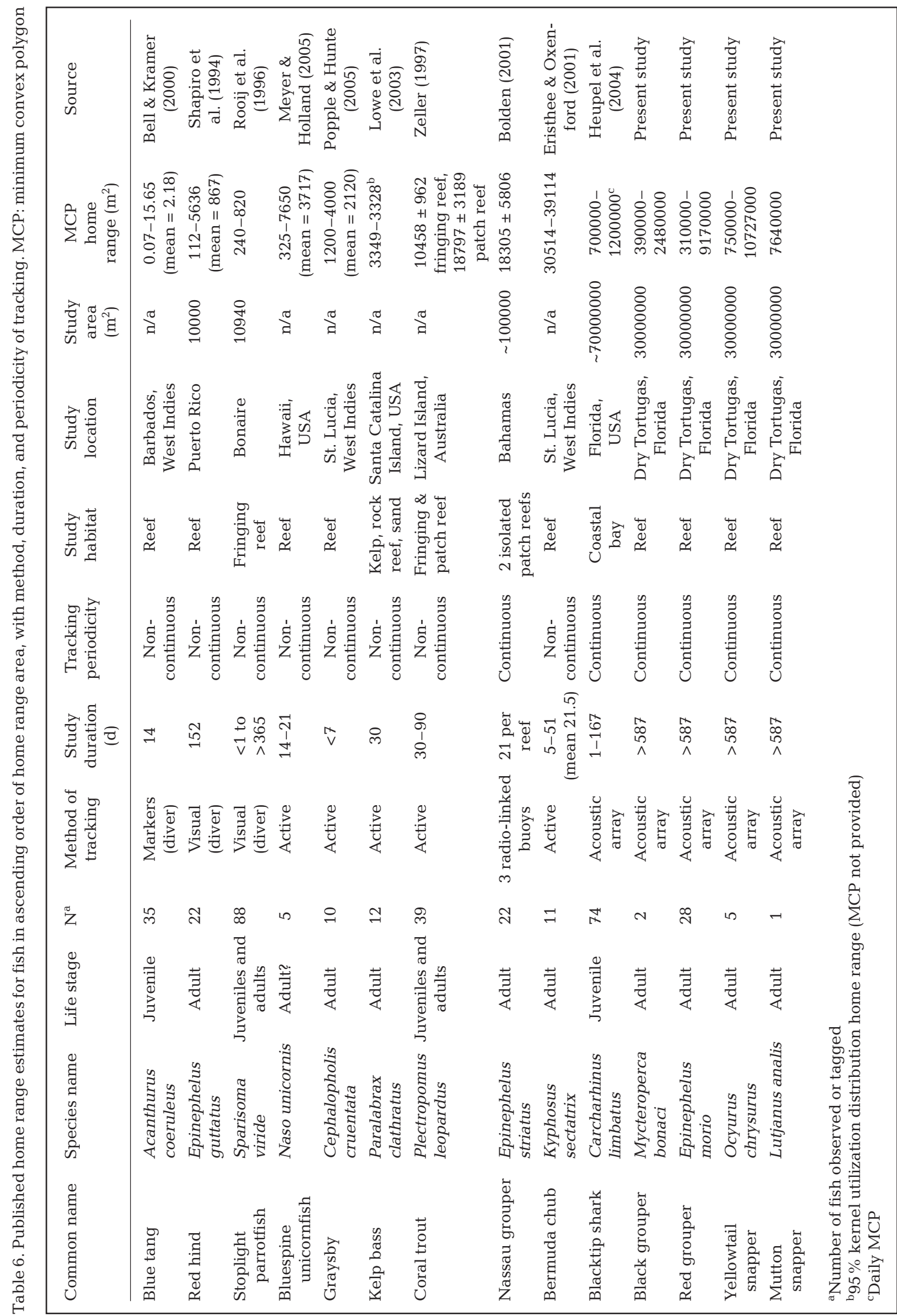


Home range size may also be a function of predation risk, body size and bioenergetic requirements, intraspecific interactions and territoriality, or reproductive dynamics (reviews in Harris et al. 1990, McLoughlin \& Ferguson 2000). Relative to most marine habitats in the Florida Keys, the coral reefs of the Tortugas have high concentrations of resources, high conspecific competition, and high predation risk. As such, theory would suggest that snapper and grouper home ranges in other regions might be larger than those observed in this study. Our home range estimates for all tracked species higher than those previously estimated for other reef species (see Table 6). However, it is important to note that the perception of mobility is dependent upon the scale of time and space over which movement is monitored (Steingrímsson \& Grant 2003). Most active tracking and diver-based studies of fish movement are constrained in the duration and periodicity of observations, often representing less than 1 mo of sporadic observations of animal movements and missing important diel and ontogenetic transitions in space use (Table 6). In our study, most fish required longer than 1 mo to reach asymptotic home range size. Many previous studies have been constrained in the diel period of observations. In our study, red grouper moved greater distances and with greater frequency during daylight hours, and nocturnal movement frequency was highest when fish could take advantage of moderate light levels to more efficiently capture prey (Helfman 1993). Finally, many previous studies have been constrained in their spatial scale. Undetected movements out of a study area would result in underestimation of home range size. The broad spatial and temporal scale of our study may partially explain our relatively large observed home ranges.

NTMRs such as the RNA may provide numerous benefits, including increased biomass of exploited species through reduced harvest, and unexploited species through reduced bycatch, restoration of natural community dynamics, and protection of coral reef habitats (see review in Bohnsack et al. 2004). Thus, the value of the Tortugas NTMR network as a habitat and foraging ground for sedentary and highly mobile species may increase through time (Bartholomew et al. 2008). Our observations suggest that these NTMRs may promote surrounding fisheries, in the near-term through spillover into fishable areas, and in the long-term through increased spawning stock biomass. Recent assessments have suggested improvements in the status of mutton snapper (SEDAR-15 2008), red grouper (SEDAR-12 Update 2009, SEDAR-19b 2010) and black grouper (Ault et al. 2006b; SEDAR-19a 2010) stocks, which may be partially attributable to the Tortugas NTMR network. NTMR effectiveness probably depends upon the reserve being sited over large expanses of contiguous reef. Alignment of NTMR boundaries with natural deterrents to movement may minimize spillover, especially if the NTMR encompasses preferred habitats. Key habitat features, such as nocturnal foraging habitats and spawning aggregation sites, may also require protection. Future studies should focus on expanding the temporal and spatial scales of acoustic monitoring and the numbers and size ranges of individuals tagged and tracked to fully quantify the rate of flux between protected and unprotected areas.

Acknowledgements. This research was supported by National Park Service CESU contract H5000065040-J5281060165 and NOAA NMFS Coral Reef Conservation Program Grants NA17RJ1226 and NA08OAR4320892. Graduate support was provided to N.A.F. by an ASEE National Defense Science and Engineering Graduate Fellowship and a University of Miami Doctoral Fellowship. We thank Superintendent D. Kimball and Assistant Superintendent R. Howard of Dry Tortugas National Park, and B. Causey of the Florida Keys National Marine Sanctuary, for funding, permits, and access to resources. We thank the following for additional support: Florida Foundation for Responsible Angling; International Light Tackle Tournament Association; International Women's Fishing Association Ryan Kelley Memorial Scholarship; Marine Technology Society; PADI Project AWARE; SEASPACE; Yamaha Contender Miami Billfish Tournament; University of Miami Small Boats Program; Yankee Fleet of Key West; Costa del Mar; National Marine Fisheries Service; G. Kelley; S. Donahue; The Calloway Family; American Institute of Fishery Research Biologists; US Geological Survey; Stock Island Oceanside Marina; Andy Griffiths Charters of Key West, Florida; D. B. Olson, N. M. Ehrhardt, and J. W. McManus of the University of Miami; and our many field volunteers. All research was in full compliance with the University of Miami Institutional Animal Care and Use Committee.

\section{LITERATURE CITED}

Atwood TC, Weeks HP Jr (2003) Spatial home-range overlap and temporal interaction in eastern coyotes: the influence of pair types and fragmentation. Can J Zool 81:1589-1597

Ault JS, Bohnsack JA, Meester GA (1998) A retrospective (1979-1996) multispecies assessment of coral reef fish stocks in the Florida Keys. Fish Bull 96:395-414

Ault JS, Smith S, Luo J, Meester GA, Bohnsack JA, Miller SL (2002) Baseline multispecies coral reef fish stock assessment for Dry Tortugas, Tech Memo NMFS-SEFSC-487. National Oceanic and Atmospheric Administration, Washington, DC

Ault JS, Bohnsack JA, Smith SG, Luo J (2005a) Towards sustainable multispecies fisheries in the Florida USA coral reef ecosystem. Bull Mar Sci 76:595-622

Ault JS, Smith SG, Bohnsack JA (2005b) Evaluation of average length as an indicator of exploitation status for the Florida coral-reef fish community. ICES J Mar Sci 62: $417-423$

Ault JS, Smith SG, Bohnsack JA, Luo J, Farmer NA, Harper DE, McClellan DB (2006a) Fishery-independent monitoring of coral reef fishes, coral reefs, and macroinvertebrates in the Dry Tortugas. Final Report to the National Park Service and National Marine Fisheries Service, University of Miami, FL

Ault JS, Smith SG, Bohnsack JA, Luo J, Harper DE, McClellan DB (2006b) Building sustainable fisheries in 
Florida's coral reef ecosystem: positive signs in the Dry Tortugas. Bull Mar Sci 78:633-654

Ault JS, Smith SG, Farmer NA, Schmidt T (2007a) Fisheryindependent monitoring of coral reef fishes, coral reefs, and macro-invertebrates in the Dry Tortugas. Final Report to the National Park Service and National Marine Fisheries Service, University of Miami, FL

Ault JS, Smith SG, Tilmant JT (2007b) Fishery management analyses for reef fish in Biscayne National Park: bag \& size limits, Natural Resource Technical Report NPS/NRPC/ WRD/NRTR-2007/064. National Park Service, Washington, DC

Ault JS, Smith SG, Tilmant JT (2009) Are the coral reef finfish fisheries of south Florida sustainable? Proc 11th Int Coral Reef Symp 11:989-993

Baras E, Togola B, Sicard B, Bénech V (2002) Behaviour of tigerfish Hydrocynus brevis in the River Niger, Mali, as revealed by simultaneous telemetry of activity and swimming depth. Hydrobiologia 483:103-110

Barrett NS (1995) Short- and long-term movement patterns of six temperate reef fishes (Families Labridae and Monacanthidae). Mar Freshw Res 46:853-860

Bartholomew A, Bohnsack JA, Smith SG, Ault JS, Harper DE, McClellan DB (2008) Influence of marine reserve size and boundary length on the initial response of exploited reef fishes in the Florida Keys National Marine Sanctuary, USA. Landscape Ecol 23(Suppl. 1):55-65

Bell T, Kramer DL (2000) Territoriality and habitat use by juvenile blue tangs, Acanthurus coeruleus. Environ Biol Fishes 58:401-409

Beyer HL (2004) Hawth's analysis tools for ArcGIS. www. spatialecology.com/htools

Bohnsack JA, Ault JS, Causey B (2004) Why have no-take marine protected areas? Am Fish Soc Symp 42:185-193

Bolden SK (2001) Nassau grouper (Epinephelus striatus, Pisces: Serranidae) movement in the Bahamas, as determined by ultrasonic telemetry. PhD dissertation, University of Miami, FL

Brown JL (1964) The evolution of diversity in avian territorial systems. Wilson Bull 76:160-169

Burt WH (1943) Territoriality and home range concepts as applied to mammals. J Mammal 24:346-352

Burton ML, Brennan KJ, Múñoz RC, Parker RO Jr (2005) Preliminary evidence of increased spawning aggregations of mutton snapper (Lutjanus analis) at Riley's Hump two years after establishment of the Tortugas South Ecological Reserve. Fish Bull 103:404-410

> Carpenter FL, MacMillen RE (1976) Threshold model of feeding territoriality and test with a Hawaiian honeycreeper. Science 194:639-642

Claro R (1981) Ecología y ciclo de vida del pargo criollo, Lutjanus analis (Cuvier), en la plataforma cubana. Acad Cienc Cuba. Inf Cient Téc Acad Cienc Cuba 186:1-83

> Clements S, Jepsen D, Karnowski M, Schreck CB (2005) Optimization of an acoustic telemetry array for detecting transmitter-implanted fish. N Am J Fish Manag 25: 429-436

Coleman FC, Koenig CC, Collins LA (1996) Reproductive styles of shallow-water groupers (Pisces: Serranidae) in the eastern Gulf of Mexico and the consequences of fishing spawning aggregations. Environ Biol Fishes 47: 129-141

Collins LA, Fitzhugh GR, Lombardi-Carlson LA, Lyon HM, Walling WT, Oliver DW (2002) Characterization of red grouper (Serranidae: Epinephelus morio) reproduction from the eastern Gulf of Mexico, Panama City Laboratory Contribution Series 2002-07. National Marine Fisheries
Service, NOAA, Panama City, FL

Crabtree RE, Bullock LH (1998) Age, growth, and reproduction of black grouper, Mycteroperca bonaci, in Florida waters. Fish Bull 96:735-753

Eklund AM, McClellan DB, Harper DE (2000) Black grouper aggregations in relation to protected areas within the Florida Keys National Marine Sanctuary. Bull Mar Sci 66: 721-728

Eristhee N, Oxenford HA (2001) Home range size and use of space by Bermuda chub Kyphosus sectatrix (L.) in two marine reserves in the Soufrière Marine Management Area, St. Lucia, West Indies. J Fish Biol 59(Suppl. A): $129-151$

Faraway JJ (2006) Extending the Linear Model with R. Chapman \& Hall/CRC, New York, NY

Farmer NA (2009) Reef fish movements and marine reserve designs. PhD dissertation, University of Miami, Coral Gables, FL

Fitzhugh GR, Lyon HM, Walling WT, Levins CF, LombardiCarlson LA (2006) An update of Gulf of Mexico red grouper reproductive data and parameters for SEDAR 12, Panama City Laboratory Contribution 06-14. National Marine Fisheries Service, NOAA, Panama City, FL

Franklin EC, Ault JS, Smith SG, Luo J and others (2003) Benthic habitat mapping in the Tortugas region, Florida. Marine Geodesy 26:19-34

Goeden G (1978) A monograph of the coral trout Plectropomus leopardus (Lacepède), Res Bull Vol. 1. Queensland Fisheries Service, Brisbane

> Harris S, Cresswell WJ, Forde PG, Trewhella WJ, Woollard T, Wray $S$ (1990) Home-range analysis using radio-tracking data: a review of problems and techniques particularly as applied to the study of mammals. Mammal Rev 20: $97-123$

Helfman GS (1993) Fish behaviour by day, night, and twilight. In: Pitcher TJ (ed) The behaviour of teleost fishes, 2nd edn. Chapman \& Hall, London, p 479-512

Heupel MR, Simpfendorfer CA, Hueter RE (2004) Estimation of shark home ranges using passive monitoring techniques. Environ Biol Fish 71:135-142

Hilborn R (2006) Faith-based fisheries. Fisheries 31:554-555

Hooge PN, Eichenlaub B (2000) Animal movement extension to Arcview ver. 2.0. Alaska Science Center, Biological Science Office, U.S. Geological Survey, Anchorage, AK

> Kellner JB, Tetreault I, Gaines SD, Nisbet RM (2007) Fishing the line near marine reserves in single and multispecies fisheries. Ecol Appl 17:1039-1054

Kramer DL, Chapman MR (1999) Implications of fish home range size and relocation for marine reserve function. Environ Biol Fishes 55:65-79

Laundré JW, Keller BL (1984) Home range size in coyotes: a critical review. J Wildl Manag 48:127-139

Lembo G, Spedicato MT, Økland F, Carbonara P and others (2002) A wireless communication system for determining site fidelity of juvenile dusky groupers Epinephelus marginatus (Lowe, 1834) using coded acoustic transmitters. Hydrobiologia 483:249-257

Lindeman KC, Pugliese R, Waugh GT, Ault JS (2000) Development patterns within a multispecies reef fishery: management applications for essential fish habitats and protected areas. Bull Mar Sci 66:929-956

> Løkkeborg S, Ferno A, Jorgensen T (2002) Effect of positionfixing interval on estimated swimming speed and movement pattern of fish tracked with a stationary positioning system. Hydrobiologia 483:259-264

Lowe CG, Topping DT, Cartamil DP, Papastamatiou YP (2003) Movement patterns, home range, and habitat utilization of 
adult kelp bass Paralabrax clathratus in a temperate notake marine reserve. Mar Ecol Prog Ser 256:205-216

Luo J, Serafy JE, Sponaugle S, Teare PB, Kieckbusch D (2009) Movement of gray snapper Lutjanus griseus among subtropical seagrass, mangrove, and coral reef habitats. Mar Ecol Prog Ser 380:255-269

MacDonald D (1983) The ecology of carnivore social behavior. Nature 301:379-384

MacDonald D, Ball F, Hough N (1980) The evaluation of home range size and configuration using radio tracking data. In: Amlaner C, MacDonald D (eds) A handbook on biotelemetry and radio tracking. Pergamon Press, Oxford, p 405-424

McCauley RD (1994) Distributions and levels of snapping shrimp noise in northern Australia. Report for the Defense Science and Technology Organization

McLoughlin PD, Ferguson SH (2000) A hierarchical sequence of limiting factors may help explain variation in home range size. Ecoscience 7:123-130

Meester GA, Ault JS, Smith SG, Mehrotra A (2001) An integrated simulation modeling and operations research approach to spatial management decision making. Sarsia 86:543-558

Meester GA, Mehrotra A, Ault JS, Baker EK (2004) Designing marine reserves for fishery management. Manag Sci 50:1031-1043

Meyer CG, Holland KN (2005) Movement patterns, home range size and habitat utilization of the bluespine unicornfish, Naso unicornis (Acanthuridae) in a Hawaiian marine reserve. Environ Biol Fish 73:201-210

Meyer CG, Papastamatiou YP, Holland KN (2007) Seasonal, diel, and tidal movements of green jobfish (Aprion virescens, Lutjanidae) at remote Hawaiian atolls: implications for marine protected area design. Mar Biol 151:2133-2143

Moe MA Jr (1972) Movement and migration of south Florida fishes, Tech Ser No. 69. Florida Department of Natural Resources, St. Petersburg, FL

Montgomery DC (2001) Design and analysis of experiments, 5th edn. John Wiley \& Sons. New York, NY

$>$ Nemtzov SC (1997) Intraspecific variation in home range exclusivity by female green razorfish, Xyrichtys splendens (family Labridae), in different habitats. Environ Biol Fishes 50:371-381

O'Dor R, Lindholm J, Oxenford H, Parsons D (2004) Acoustic tracking of fish: how continuous data on fish movement could change the planning of MPAs. MPA News 5:1-3

Palumbi SR (2001) The ecology of marine protected areas. In: Bertness MD et al. (eds) Marine community ecology. Sinauer Associates, Sunderland, MA, p 509-530

Parsons DM, Babcock RC, Hankin RKS, Willis TJ, Aitken JP, O'Dor RK, Jackson GD (2003) Snapper Pagrus auratus (Sparidae) home range dynamics: acoustic tagging studies in a marine reserve. Mar Ecol Prog Ser 262:253-265

Paz G, Sedberry GR (2007) Identifying black grouper (Mycteroperca bonaci) spawning aggregations off Belize: conservation and management. Proc Gulf Caribb Fish Inst 60:577-584

Pincock DG, Voegeli FW (2002) A quick course in underwater telemetry systems. VEMCO Ltd., Halifax, NS

Pinheiro JC, Bates DM (2000) Mixed-effects models in S and S-PLUS. Springer, New York, NY

Popple ID, Hunte W (2005) Movement patterns of Cephalopholis cruentata in a marine reserve in St Lucia, W.I., obtained from ultrasonic telemetry. J Fish Biol 67(4): 981-992

Rooij JM, Kroon FJ, Viedeler JJ (1996) The social and mating system of the herbivorous reef fish Sparisoma viride; onemale versus multi-male groups. Environ Biol Fishes 47: 353-378

> Russ GR, Alcala AC (1996) Do marine reserves export adult fish biomass? Evidence from Apo Island, central Philippines. Mar Ecol Prog Ser 132:1-9

Schenkel R (1966) Zum Problem der Territorialität und des Markierens bei Säugern-am Beispiel des Schwarzen Nashorns und des Löwens. Z Tierpsychol 23:593-626

Schmidt TW, Ault JS, Bohnsack JA, Luo J and others (1999) Site characterization for the Dry Tortugas region: fisheries and essential habitats, Tech Mem NMFS-SEFSC-000. National Marine Fisheries Service, NOAA, Miami, FL

SEDAR-15 (Southeast Data, Assessment, and Review) (2008) Gulf of Mexico and South Atlantic mutton snapper. SEDAR, North Charleston, SC

SEDAR-12 (Southeast Data, Assessment, and Review) Update (2009) Stock assessment of red grouper in the Gulf of Mexico. Report of Assessment Workshop, SEDAR, Miami, FL

SEDAR-19a (Southeast Data, Assessment, and Review) (2010) Gulf of Mexico and South Atlantic black grouper. SEDAR, North Charleston, SC

SEDAR-19b (Southeast Data, Assessment, and Review) (2010) South Atlantic red grouper. SEDAR, North Charleston, SC

Shapiro DY, Garcia-Molina G, Sadovy Y (1994) Social system of an inshore stock of the red hind grouper, Epinephelus guttatus (Pisces: Serranidae). Environ Biol Fishes 41: 415-422

Simpfendorfer CA, Heupel MR, Hueter RE (2002) Estimation of short-term centers of activity from an array of omnidirectional hydrophones and its use in studying animal movements. Can J Fish Aquat Sci 59:23-32

Smith SG, Ault JS, Bohnsack JA, Harper DE, Luo J, McClellan DB (2011) Multispecies survey design for assessing reef-fish stocks, spatially explicit management performance, and ecosystem condition. Fish Res 109:25-41

Steingrímsson SÓ, Grant JWA (2003) Patterns and correlates of movement and site fidelity in individually tagged young-of-the-year Atlantic salmon (Salmo salar). Can J Fish Aquat Sci 60:193-202

Stenger J (1958) Food habits and available food for ovenbirds in relation to territory size. Auk 75:335-346

Tremain DM, Harnden CW, Adams DH (2004) Multidirectional movements of sportfish species between an estuarine no-take zone and surrounding waters of the Indian River Lagoon, Florida. Fish Bull 102:533-544

Voegeli FA, Pincock DG (1996) Overview of underwater acoustics as it applies to telemetry. In: Baras E, Philippart JC (eds) Underwater biotelemetry. Proc 1st Conf Fish Telem Europe. University of Liège, p 235-241

Wilson EO (1975) Sociobiology: the new synthesis. Belknap Press, Cambridge, MA

Winter JD, Ross MJ (1982) Methods in analyzing fish habitat utilization from telemetry data. In: Armantrout NB (ed.) Proc Symp Acquisition and Utilization of Aquatic Habitat Inventory Information. American Fisheries Society, Bethesda, MD, p 273-279

Young PH (1963) The kelp bass (Paralabrax clathratus) and its fishery, 1947-1958, Bulletin 122. California Department of Fish and Game, Sacramento, CA

Zeller DC (1997) Home range and activity patterns of the coral trout Plectropomus leopardus (Serranidae). Mar Ecol Prog Ser 154:65-77

Zuur AF, Ieno EN, Walker NJ, Saveliev AA, Smith GM (2009) Mixed effects models and extensions in ecology with R. Springer Science-Business Media, New York, NY 